\title{
The Role Of Village Credit Institutions (LPD) In Realizing The Economic Institutions Of The Traditional Village Krama Community In Bali
}

\author{
Komang Febrinayanti Dantes ${ }^{1}$, Ketut Sudiatmaka ${ }^{1}$, Ni Ketut Sari Adnyani ${ }^{1}$ \\ febrinayanti.dantes@undiksha.ac.id, ktsudiatmaka1@gmail.com, niktsariadnyani@gmail.com,
}

${ }^{1}$ Universitas Pendidikan Ganesha, Indonesia

\begin{abstract}
The purpose of this research is to find out (1) the mechanism for establishing, administering and managing LPDs based on customary law in Bali; (2) The legal position and function of the LPD as a community economic institution in the banking legal system; and (3) The role of the Bali Regional Government in fostering and developing the LPD as a community economic institution. The type of research used is normative legal research, using a statute approach and a case approach. The legal materials used are primary legal materials, secondary legal materials, and tertiary legal materials. The technique of collecting legal materials is a technique of document study and is analyzed according to the problems studied in a qualitative juridical manner. hoped that the LPD management will prioritize lending to those who really need it. The management must also remember the spirit of the founding of the LPD. LPD was established to create equity and business opportunities for villagers so that later on the poverty rate in the customary village area.
\end{abstract}

Key words: Traditional Village; LPD; welfare; krama .

\section{Introduction}

The Bali Provincial Regulation Number 4 of 2019 concerning Traditional Villages in Bali clearly defines a customary village as a unit of customary law community in the province of Bali which has a unity of traditions and manners of social life of the Hindu community from generation to generation in the bonds of kahyangan three or kahyangan desa. who has a certain area and own assets and has the right to manage his own household.

Traditional village is a social religious community unit that is autonomous, has the right to take care of its own household. This right is hereinafter referred to as the traditional rights of customary law communities which are recognized and respected by the state as regulated in Article 18 B paragraph 2 of the 1945 Constitution of the Republic of Indonesia, "The state recognizes and respects customary law community units and their traditional rights as long as still alive and in accordance with the development of society and the principles of the Unitary State of the Republic of Indonesia as regulated by law [1]. 
Based on the Bali Provincial Regulation Number 4 of 2019 concerning Traditional Villages in Bali, ${ }^{2}$ it states that every Traditional Village has awig-awig, awig-awig is a rule made by traditional villages and/or customary banjars that apply to customary village manners, which regulates parayangan, pawongan, and the weakening of the Traditional Village. Every village has a pararem, pararem is the regulation/decision of the adat village as the implementation of awig-awig or regulating new things and/or resolving traditional cases in the adat village. and peace of scale and nobility, besides that, traditional villages also have the task of developing the village economy, one of which is through financial institutions belonging to traditional villages, namely the Village Credit Institution [2] .

Village Credit Institutions as community financial institutions that are unique and specific to the customary law community in Bali in the context of implementing state politics in regulating customary law community units appropriately, in accordance with the contents of the state constitution. the uniqueness and particularity of the implementation of Village Credit Institutions with customary conditions in Bali where adat is a reflection of the personality of a nation and the embodiment of the soul of the nation concerned. Customs that live and are related to folk traditions are the source of customary law., as quoted by Surojo Wignjodipuro, said that customary law is used as a synonym for laws that are not written in legislative regulations (unstraturory law) including life regulations that although not determined by the authorities, they are still adhered to and supported by the people based on the belief that the validity of these regulations has legal force (Central Bureau of Statistics [3].

Given the increasingly urgent need for capital for rural communities, the local government, especially the Bali Provincial Government, has begun to develop financial institutions in rural communities, known as the Village Credit Institution. In its development, as an effort to ensure more certainty and legal protection for the existence and activities of the Village Credit Institution as an institution that carries out financial functions belonging to traditional villages and village manners that are members, Regional Regulation No. 8 of 2002 concerning Village Credit Institutions that have amended Regional Regulation No. 4 of 2012 and amended again by Regional Regulation No. 3 of 2017 concerning the second amendment to the Bali Provincial Regulation No. 8 of 2002 concerning Village Credit Institutions. Based on Regional Regulation Number 3 of 2017 it is stated that Villages can have business entities, and for that villages in Bali, especially in Pakraman Village, are established Village Credit Institutions. The existence of the Village Credit Institution is very positive for the development of the village economy. Village Credit Institutions are financial institutions belonging to Traditional Villages that have developed, providing social, economic and cultural benefits to the community, so that in the future it needs to be fostered, improved performance, and preserved its existence [4].

In order to support the smooth development and economy in rural areas as well as improve traditional villages, the presence of the Village Credit Institution can strengthen the finances of the Traditional Village, because the Village Credit Institution operates in savings and loans like banking. Development of Village Credit Institutions requires the role of Law Adat is in the form of awig-awig which contains customary sanctions against those who violate the awig-awig of the Traditional Village related to the Village Credit Institution.

Based on the Bali Provincial Regulation Number 4 of 2019 concerning Traditional Villages in Bali Article 61 paragraph (2) Village Credit Institutions are recognized for their 
existence, are formed, regulated and managed based on customary law ${ }^{5}$. Which can be interpreted as the Village has the right to make awig-awig and pararem for the development of the Village Credit Institution which contains customary sanctions in accordance with the awig-awig made. This is important because Traditional Villages have an important role in solving existing problems related to the progress of the Village Credit Institution.

The Role of Traditional Villages in managing the Development of Village Credit Institutions (LPD) Based on Regional Regulation Number 3 of 2017 concerning Village Credit Institutions (a case study in Telaga Village, Busungbiu District, Buleleng Regency) is very important to do considering the role of the Village Credit Institution is very influential on the progress of a Traditional Village, especially in the economic field, so in this case the Traditional Village should very significantly regulate matters related to the development and progress of the Village Credit Institution through awig-awig. So that the existence and sustainability of the Institution Village Credit continues to run to advance the economy of Traditional Villages.

\section{Method}

Legal research is an activity based on certain methods, systematics, and thoughts whose purpose is to study one or several legal phenomena and then find a solution to the problems that arise in the symptoms concerned ${ }^{6}$. The type of research used in this research is normative research.

Legal research is a research that consists of several approaches, through this approach the author will get information from various aspects regarding the content being answered. Regarding this research, there are 2 (two) types of approaches, namely the statutory approach and the case approach [5], [6].

Related to this research, the author uses several sources of legal materials consisting of: Primary legal materials are legal materials that contain new or current scientific knowledge or new understanding of known facts or ideas ${ }^{7}$. The legal materials used in this research include: the 1945 Constitution of the Republic of Indonesia (UUD NRI 1945); Civil Code (KUHPerdata). Secondary legal materials contain information or clarity about primary materials ${ }^{8}$. Legal materials used include: a. Legal literature on LPD; b. Legal research on LPD; c. Legal journal on LPD; d. Legal Thesis, Thesis, Dissertation on LPD; e. Articles related to LPD problems in Bali Province [7], [8].

Tertiary legal materials are non-legal materials or supporting materials used to explain and provide an overview of primary legal materials and secondary legal materials such as dictionaries, basic norm hierarchies, basic regulations and laws and regulations. Regarding this research, the author uses the Legal Dictionary and the Big Indonesian Dictionary (KBBI) in translating legal sentences that are difficult to understand. The collection of legal materials that the author uses is a document study technique, namely in collecting legal materials from library sources that are relevant to the problems discussed by reading and taking notes through the card system to facilitate analyzing problems ${ }^{9}$. The technique of collecting statutory legal 
materials in this study must start from searching various legal materials that are indirectly related to the problem under study so as to obtain relevant answers.

\section{Result and Discussion}

Mechanism of Establishment, Management and Management of LPD Based on Customary Law in Bali

The legal position and function of the LPD as a People's Economic Institution in the Banking Law System LPD as a financial institution belonging to the indigenous village community whose credit guarantee binding follows the provisions of the Fiduciary Law and the Mortgage Law which is not appropriate. The reason is, in the Mortgage Law it is stated that the Mortgage Holder is an individual or legal entity domiciled as a debtor. Meanwhile, the Fiduciary Guarantee Law states that the Fiduciary Guarantee Holder is an individual or corporation. LPDs which are communally owned, of course, cannot be categorized as individuals or private companies. Its position as a duwe adat village that is subject to customary law gives LPD a special status and position.

To strengthen this, the LPD in current practice does not have any rights (be it ownership rights, use rights, use rights, building rights, and other rights that are commonly owned by an incorporated and legal business entity). If there is a case/dispute that an LPD debtor (krama desa adat) is in default (in this case unable or unable to pay credit) and is taken to confiscate the collateral through the auction process and the LPD decides to buy the collateral itself through the auction process, then the one listed as the auction buyer is the head of the relevant LPD. Not infrequently, there is an individual head of the LPD who lists himself as a Mortgage Holder or a Fiduciary Guarantee Holder because of the lack of knowledge of the people in remote villages in Bali about the law. This is very risky if an LPD Chair or the heirs of the LPD Chair have bad intentions, there can be cases of misuse of collateral.

It is appropriate to refer to the provisions of Law Number 1 of 2013 concerning Microfinance Institutions which states that LPDs must comply with customary law and it has been explained that LPDs are customary village duwe with very different characteristics from BPRs and village-owned enterprises, this provision should be reviewed return.

If the LPD status has been confirmed as a customary village duwe and a transitional regulation has been made that gives the LPD regulatory authority to the adat authority, then all components concerning the LPD, including those related to the binding of guarantees, must also be adjusted to the adat concept. If the guarantee binding is also changed, the contractual agreements must also be adjusted. When a customary village krama will apply for credit, then the contract agreements must be based on adat by referring to Balinese customary law with the necessary adjustments to comply with Balinese customary law applicable in the local adat village. The study of contractual agreements in Balinese customary law, one of which can refer to debt law in adat.

\section{Legal Position and Function of LPD as a Community Economic Institution in the Banking Legal System}

LPD as a financial institution belonging to the indigenous village community whose credit guarantee binding follows the provisions of the Fiduciary Law and the Mortgage Law which is not appropriate. The reason is, in the Mortgage Law it is stated that the Mortgage Holder is an individual or legal entity domiciled as a debtor. Meanwhile, the Fiduciary Guarantee Law states that the Fiduciary Guarantee Holder is an individual or corporation. LPDs which are communally owned, of course, cannot be categorized as individuals or private 
companies. Its position as a duwe adat village that is subject to customary law gives LPD a special status and position.

To strengthen this, the LPD in current practice does not have any rights (be it ownership rights, use rights, use rights, building rights, and other rights that are commonly owned by an incorporated and legal business entity). If there is a case/dispute that an LPD debtor (krama desa adat) is in default (in this case unable or unable to pay credit) and is taken to confiscate the collateral through an auction process and the LPD decides to purchase the collateral itself through the auction process, then the one listed as the auction buyer is the head of the relevant LPD. Not infrequently, there is an individual head of the LPD who lists himself as a Mortgage Holder or a Fiduciary Guarantee Holder because of the lack of knowledge of the community in remote villages in Bali about the law. This is very risky if an LPD Chair or the heirs of the LPD Chair have bad intentions, there can be cases of misuse of collateral. So, it is appropriate to refer to the provisions of Law Number 1 of 2013 concerning Microfinance Institutions which states that LPDs must comply with customary law and it has been explained that LPDs are customary village duwe with very different characteristics from BPRs and village-owned enterprises. this deserves to be reconsidered. If the status of the LPD has been confirmed as a customary village duwe and a regional regulation has made a transitional regulation that gives the LPD regulatory authority to the customary authority, then all components related to the LPD including those related to the binding of guarantees must also be adapted to the adat concept. , then the contract agreements must also be adjusted. When a customary village krama will apply for credit, then the contract agreements must be based on adat by referring to Balinese customary law with the necessary adjustments to comply with Balinese customary law applicable in the local adat village. The study of contractual agreements in Balinese customary law, one of which can refer to debt law in adat [9].

\section{The Role of the Bali Regional Government in Fostering and Developing the LPD as a People's Economic Institution}

The Regional Government of Bali Province determines LPD based on Regional Regulations (Perda) Bali Province Number 8 of 2002 in Article 2 paragraph (1) confirms that regarding LPD it is stated that LPD is a village-owned financial business entity that carries out business activities in the village environment and for village manners. These provisions indicate that LPD is a form of economic institution, which is recognized by the Regional Regulation and confirmed in legal status as a form of financial business entity, with a special nature, because it only carries out business activities within the customary village area.

The local government of Bali Province has provided assistance since the establishment of the LPD, which is expected to (1) be able to encourage the economic development of the people in the Bali area through targeted savings and effective capital distribution, (2) to eradicate the bondage system, illegal pawning and others that can be equated with it. in rural areas, (3) creating equity and employment opportunities for rural residents, both of which can be accommodated by the community's productive efforts financed by the LPD, and (4) increasing purchasing power and facilitating payment traffic and money circulation in the village.[10]

Since its inception, LPD has achieved excellent performance. Based on data from Bank BPD Bali, after the provincial government targeted establishment of an LPD in each customary village, the number of operating LPDs increased from 953 in 2001 and became 1,418 in 2011. Please note, the Village Credit Institution (LPD) is a financial enterprise owned by traditional villages in Bali. LPD is a financial business entity that is excluded or not subject to the Law on Microfinance Institutions (LKM) Number 1 of 2013 and is only based on 
customary law in Bali. As of December 2020, there are 1,493 traditional villages in Bali. Of the number of traditional villages, village credit institutions formed reached 1,436 LPDs or 96.2 percent of the existing traditional villages. However, only 91.1 percent or 1,308 LPDs operate. A total of 128 LPDs are recorded as not operating anymore. As for the 1,308 LPDs operating in Bali until the end of 2020, the number that experienced a decline in assets was 541 LPDs or 41.7 percent. The ratio of LPDs that experienced an increase in assets reached 58.3 percent or as many as $757 \operatorname{LPDs}^{10}$.

The contribution of the Provincial Government of Bali as a partner of the LPD in poverty alleviation is very dependent on the profit of the LPD concerned. Conceptually according to Regional Regulation No. 8 of 2002 which has been revised into Perda No. 4 of 2012, the distribution of the remaining operating results (profit) of the LPD is mostly enjoyed by the adat villagers concerned. If the profit decreases, the allocation to the welfare of the community will automatically increase Thus, there are two paths in poverty alleviation in Indonesia rural areas in Bali Province. LPD's first line of financing small businesses, the next path is a small business to create jobs and at the same time overcome poverty. Bank BPD Bali mentions four positive impacts of LPD for development rural areas, namely: 1) with the existence of the LPD, the traditional village has received a source of funding development by 20 percent of net profit, while for other interests sourced from social funds in the amount of 5 percent; 2) LPD has participated in supporting government programs in terms of poverty alleviation, as well as expanding opportunities work; 3) participate in encouraging the growth rate of small industries in rural areas so that the economic growth of rural communities is getting better; and 4) with success achieved, LPD also acts as the object of research on empowerment people's economy.

Socially and religiously, the role of the LPD in Bali is also very clear. As regulated in article 22 of the LPD regional regulation, it is stated that the distribution of LPD net profits at the end of the year will be used for capital reserves of 60 percent, village development funds 20 percent, production services 10 percent, coaching, supervision and protection funds 5 percent, and social funds 5 percent. . The regulation requires LPDs to contribute 20 percent of profits which he earns every year for the benefit of the village and the traditional banjar. Beside used for the physical development of villages and banjars, part of the funds obtained from The LPD, by the villagers is usually also used to finance other activities. religious ceremonies. This means that in addition to having an economic function that broadly, LPDs also have a very high social and religious function throughout Bali. Another tangible contribution that LPD has successfully made is in terms of: reduce the cost of the ceremony. There are several LPDs that organize Contribution programs Ngaben funds whose funds can only be disbursed during the Ngaben ceremony. The community is very enthusiastic about welcoming this program because it is felt to be useful very. Society becomes lighter in burden so that it can create silence and holiness in carrying out the ceremony without having to think about excessive funding burdens ${ }^{11}$.

Socially and religiously, the role of the LPD in Bali is also very clear. As regulated in article 22 of the LPD regional regulation, it is stated that the distribution of LPD net profits at the end of the year will be used, for a capital reserve of 60 percent, 20 percent of village development, 10 percent of production services, coaching funds, supervision and 5 percent protection, and 5 percent social funds. The regulation requires LPD to donate 20 percent of the profits it earns annually to the interests of the village and banjar adat. 


\section{Waktu Pelaksanaannya 16.00}

The establishment of the LPD as a community financial institution is in accordance with the legal political vision of the 1945 Constitution which recognizes and respects the original village as a legal entity with all historical and cultural rights as the rights of the origin of the traditional village. The management of the LPD based on Article 1 number 29 of the Regional Regulation on Traditional Villages stated that Awig-Awig is the customary rules made by the Traditional Village and/or the Customary Banjar which apply to the Krama Desa Adat, Krama Tamiu, and Tamiu. In terms of management, LPD is also a traditional institution that carries out financial functions in traditional villages. Article 1 number 30 of the Bali Provincial Regulation No. 4/2019 concerning Traditional Villages, it is stated that the meaning of Pararem and Pararem is carried out by the Traditional Village through its Customary Prajuru as a form of rule or legal institution for the Indigenous Law Community in Bali. The position of the LPD as a duwe adat village that is subject to customary law gives the LPD a special status and position. The Provincial Government of Bali is a partner of the LPD based on the Regional Regulation (Perda) of the Province of Bali Number 8 of 2002 in Article 2 paragraph (1) confirms that regarding the LPD it is stated that the LPD is a village-owned financial business entity that carries out business activities in the village environment and for village manners.

Based on the conclusions described above, it is hoped that the LPD management will prioritize lending to those who really need it. In this case the small/poor people who are not touched by conventional banking services. The management must also remember the spirit of the founding of the LPD. That LPD was established to create equity and business opportunities for villagers so that later the poverty rate in the customary village area.

\section{References}

[1] Achmad Ali, Menguak Teori Hukum (Legal Theory) Dan TeOri Peradilan (JUDICIALPRUDENCE) TERMASUK INTERPRETASI UNDANG-UNDANG (LEGISPRUDENCE (2009).

[2] BADAN Pusat Statistik (BPS), PRofile LPd (2021).

[3] Bambang Sunggono, Metodologi Penelitian Hukum (2017).

[4] I. G. E. Damayanthi, Pengungkapan Tanggung Jawab Sosial Lembaga Perkreditan Desa (Lpd) Berdasarkan Filosofi Tri Hita Karana, 6 J. ILM. AKUNT. DAN BISNIS 17 (2011).

[5] I Ketut Sumarta, Pararem Lembaga Perkreditan Desa (LPD) Bali (2014).

[6] I Wayan. SUARTANA, ARSitekTUR PENGElolaAN Risiko PADA LeMbaga PERKREDITAN DESA (LPD) (2009).

[7] N. W. E. S. Anggereni, Pengaruh Pelatihan Terhadap Kinerja Karyawan Pada Lembaga Perkreditan Desa (Lpd) Kabupaten Buleleng, 10 J. PENDIDIK. EKON. UNDIKSHA, 606-615 (2019).

[8] Ni Putu Eka Wiratmini, Aset Lpd Di Bali Turun 3 Persen 1 (2020), Https://Bali.Bisnis.Com/Read/20210210/538/1354689/2020-Aset-Lpd-Di-BaliTurun-3-Persen.

[9] SOERJONO SOEKANTO, SOSIOlOgi, SuAtu PENGANTAR. (2012).

[10] SOERJONO SOEKANTO, POKOK-POKOK SOSIOLOGI HUKUM (2014). 